\title{
Carriers Beware! - Circumstances in Which Navigation Addresses Conflicting Liability Regimes
}

\author{
Lijun Zhao
}

(School of Law Middlesex University Hendon campus, London, NW4 4BT)

(E-mail: cn.zhaolijun@gmail.com)

\begin{abstract}
The Rotterdam Rules, as the latest marine cargo convention, seek to promote legal uniformity of multimodal transport. The network-liability approach of this convention attempts to harmonise conflicts of liability regimes among different types of navigation in multi-modal transport. However, its Articles 26 and 82 only harmonise limited scenarios among all the potential conflicts of interest. Additionally, the network-liability approach itself relies on localising any occurrence of damage to or loss of goods, which corresponds to different degrees of liability among marine, land and air navigation. Thus, it is impossible for carriers and navigators to anticipate their liabilities when entering into a contract of multimodal transport. Through analysing UNCITRAL negotiating documents, a comprehensive safeguard is proposed to solve these problems.
\end{abstract}

\section{KEYWORDS}

1. Wet Multimodal Transport.
2. Maritime Plus.
Liability.

Submitted: 7 June 2014. Accepted: 7 March 2015. First published online: 8 April 2015.

1. INTRODUCTION. Nowadays a large amount of sea cargo is shipped within containers from door to door. In order to meet this commercial need, carriers increasingly have had to handle multimodal transport and navigation on land, at sea and/or in the air in one transaction. However, carriers are exposed to legal uncertainty in multimodal transport. That is to say, one type of navigation might fall into a liability regime that usually regulates other types of navigation. A more challenging question is that conventions of various types of navigation compulsorily impose different legal requirements. Marine carriers are traditionally not liable for nautical fault, but a new seaborne cargo convention has tried to abolish this exemption. Accordingly, knowing the conflicting extent of possible liabilities is beneficial for carriers, the master and the crew. This allows them to take precautions, such as to pay extra attention to avoiding damages or to arrange sufficient insurance to cover possible risks. Therefore, 
carriers should be aware of the circumstances in which navigation triggers the applications of conflicting legal rules and take precautions.

The latest sea cargo convention - the Rotterdam Rules (RR) (UN, 2008) - seeks to regulate transport which contains at least one seaborne journey. It extends its coverage from a sea leg to other modes of transport, which is called 'maritime-plus' or 'wet' multimodal scope of application (Berlingieri, 2009). Nevertheless, this raises potential conflicts between the RR and other international instruments governing carriage by other modes of transport (Franco, 2012; Hancock, 2009). This paper attempts to identify these conflicts for carriers and navigators.

This paper focuses on the conflicts that exist among the compulsory rules relating to carriers' liability for each type of navigation. It aims to help carriers and navigators foresee the legal risks of various kinds of navigation before the occurrence of damages, and alleviate these risks through taking precautions or arranging insurance.

This paper also addresses another essential issue-how to reconcile conflicts between carriage conventions of different modes. There are two basic approaches: either to let other international conventions prevail over the RR (network liability system), or to provide uniform rules applying to all modes of transport (uniform liability system) (De Wit, 2010; Ulfbeck, 2010). The RR try to harmonise potential conflicts through a limited network system of liability under Articles 82 and 26 (Franco, 2012). These two fundamental articles regarding multimodal transport regimes will be examined in detail.

\section{THE POSSIBLY RELATED CONVENTIONS REGARDING NAVIGATION} OF WET MULTIMODAL TRANSPORT. Existing cargo conventions merely govern single modal transport, and even the RR themselves are 'maritime-plus' rather than a true multimodal convention. However, all of the various conventions include mandatory rules on liabilities with different levels of limitations of liability. Thus, conflicts arise in the event of multimodal transport. Because the majority of goods are shipped by sea, this paper focuses on wet multimodal transport, which contains a seaborne journey.

Apart from the RR, the possibly related conventions cover "the carriage of goods by air" (e.g. the Convention for the Unification of Certain Rules Relating to International Carriage by Air (Warsaw Convention; LN, 1929) and the Convention for the Unification of Certain Rules for International Carriage by Air (Montreal Convention; UN, 1999)), "the carriage of goods by road" (e.g. the Convention on the Contract for the International Carriage of Goods by Road (CMR; UN, 1956) and Carmack Amendment (US, 1906)), "the carriage of goods by rail" (e.g. the Convention Concerning International Carriage By Rail (CIM-COTIF; UN, 1952 $\& 1970)^{1}$ ), and "the carriage of goods by inland waterways" (e.g. the Budapest Convention on the Contract for the Carriage of Goods by Inland Waterway (CMNI; UN, 2001)). The conflicting rules of liability among these kinds of navigation are listed in Tables 1 and 2.

\footnotetext{
${ }^{1}$ The Convention concerning the Carriage of Goods by Rail (CIM) is modified and incorporated as Appendix B to the International convention concerning the Carriage of Goods by Rail (COTIF) from May 1999.
} 
Table 1. Monetary Limitation Levels of Existing Transport Conventions.

\begin{tabular}{|c|c|c|c|c|}
\hline $\begin{array}{l}\text { Types of } \\
\text { navigation }\end{array}$ & Convention & $\begin{array}{l}\text { Per package } \\
\text { limitation }\end{array}$ & Per kilo limitation & $\begin{array}{l}\text { Which is } \\
\text { applicable }\end{array}$ \\
\hline \multirow[t]{2}{*}{ By sea } & $\begin{array}{l}\text { Hague-Visby Rules } \\
(\mathrm{UN}, 1979)^{2}\end{array}$ & $\begin{array}{l}\text { 666.67 Special } \\
\text { Drawing } \\
\text { Rights } \\
(\text { SDRs) }\end{array}$ & 2 SDRs per kilogram & $\begin{array}{l}\text { Whichever } \\
\text { is higher }\end{array}$ \\
\hline & $\begin{array}{l}\text { Rotterdam Rules } \\
\text { (UN, 2008) }\end{array}$ & 875 SDRs & $2 \cdot 5 \mathrm{SDRs}$ & $\begin{array}{l}\text { Whichever } \\
\text { is higher }\end{array}$ \\
\hline \multirow[t]{2}{*}{$\begin{array}{l}\text { By lorry } \\
\text { (truck) }\end{array}$} & $\begin{array}{l}\text { CMR (UN, 1956) } \\
\text { Art. } 23\end{array}$ & & 8.33 SDRs & \\
\hline & $\begin{array}{l}\text { Carmack Amendment } \\
\text { (US, 1906) Art.(f) }\end{array}$ & & $\begin{array}{l}\text { an amount equal to the re- } \\
\text { placement value of such } \\
\text { goods, subject to a } \\
\text { maximum amount equal to } \\
\text { the declared value of the } \\
\text { shipment and to rules issued } \\
\text { by the (US) Surface } \\
\text { Transportation Board and } \\
\text { applicable tariffs }\end{array}$ & \\
\hline By rail (train) & $\begin{array}{l}\text { CIM-COTIF } \\
\text { (UN, } 1952 \& \text { 1970) } \\
\text { Arts. } 30 \text { and } 33\end{array}$ & & $\begin{array}{l}17 \text { SDRs per kilo of gross } \\
\text { mass short }\end{array}$ & \\
\hline $\begin{array}{l}\text { By inland } \\
\text { waterway }\end{array}$ & $\begin{array}{l}\text { CMNI (UN, 2001) } \\
\text { Art. } 20\end{array}$ & $\begin{array}{l}\text { 666.67 SDRs } \\
\text { per package } \\
\text { or other } \\
\text { loading unit }\end{array}$ & $\begin{array}{l}2 \text { SDRs per kilo of weight of } \\
\text { goods lost or damaged }\end{array}$ & $\begin{array}{l}\text { Whichever } \\
\text { is higher }\end{array}$ \\
\hline By air & $\begin{array}{l}\text { Warsaw Convention } \\
\text { (LN, 1929) Arts. } 19 \\
\text { and 22; Montreal } \\
\text { Convention (UN, } \\
\text { 1999) Art. } 22\end{array}$ & & 17 SDRs per kilo & \\
\hline $\begin{array}{l}\text { By more than } \\
\text { one mode of } \\
\text { transport }\end{array}$ & $\begin{array}{l}\text { Multimodal Convention } \\
\text { (UN, 1980; not entering } \\
\text { into force) Art. } 18\end{array}$ & $\begin{array}{l}920 \text { SDRs per } \\
\text { package or } \\
\text { other shipping } \\
\text { unit }\end{array}$ & $\begin{array}{l}2 \cdot 75 \text { SDRs per kilo of gross } \\
\text { weight of goods lost or } \\
\text { damaged }\end{array}$ & $\begin{array}{l}\text { Whichever } \\
\text { is higher }\end{array}$ \\
\hline
\end{tabular}

\footnotetext{
${ }^{2}$ Protocol to Amend the International Convention for the Unification for Certain Rules of Law Relating to Bills of Lading (Hague-Visby Rules).

${ }^{3}$ The Special Drawing Right (SDR) is an international reserve asset, created by the International Monetary Fund in 1969 to supplement its member countries' official reserves.
}

\section{INTERNATIONAL CONVENTIONS GOVERNING DIFFERENT TYPES} OF NAVIGATION - ARTICLE 82 OF THE ROTTERDAM RULES. Headed by the statement that "Nothing in this Convention [RR] affects the application of any of the following international conventions ...", Article 82 shows that the RR employ the network-liability approach to deal with potential conflicts between carriage conventions. This Article is part of Chapter 17 of the RR ("Matters not governed by this Convention"), which implies that the circumstances described within Article 82 are outside the scope of application of the RR (Berlingieri, 2009; Sturley et al., 2010).

The RR Article 82 (a) deals with the relationship between marine and air navigation in terms of liability. Subparagraph (a) aims to prevent the RR from prevailing over any convention on the carriage of goods by air (e.g. the Montreal Conventions) "to the 
Table 2. Limitation of Carriers' Liability for Delay under Existing Conventions.

\begin{tabular}{|c|c|c|}
\hline $\begin{array}{l}\text { Kinds of } \\
\text { navigation }\end{array}$ & Convention & Limitation for delay \\
\hline By sea & $\begin{array}{l}\text { Hague-Visby Rules (UN, 1979) } \\
\text { Hamburg Rules }{ }^{4} \text { (UN, 1978) Art. 6(1); Rotterdam Rules } \\
\text { (UN, 2008) Arts. } 59 \text { and 60; the UN Multimodal } \\
\text { Convention }\end{array}$ & $\begin{array}{l}\text { Not regulated } \\
2 \cdot 5 \text { times freight payable for/ } \\
\text { on goods delayed }\end{array}$ \\
\hline By lorry & CMR (UN, 1956) Art. 23 & the carriage charges \\
\hline By train & CIM-CITIF (UN, $1952 \& 1970)$ Arts. 30 and 33 & $\begin{array}{l}4 \text { times the carriage charges } \\
\text { for the goods lost }\end{array}$ \\
\hline $\begin{array}{l}\text { By inland } \\
\text { waterway }\end{array}$ & CMNI (UN, 2001) Art. 20 & the value of the freight \\
\hline By air & $\begin{array}{l}\text { Warsaw Convention (LN, 1929) Arts. } 19 \text { and 22; Montreal } \\
\text { Convention (UN, 1999) Art. } 22\end{array}$ & 17 SDRs per kilo \\
\hline
\end{tabular}

${ }^{4}$ The United Nations Convention on the Carriage of Goods by Sea (Hamburg Rules).

extent that such convention according to its terms applies to any part of the contract of carriage". Even though the Montreal Convention (UN, 1999) does not govern any period of "carriage by land, by sea or by inland waterway outside an airport", two exceptions fall within the Montreal Convention's coverage (under Articles 38 and 18.4). First, if air navigation takes place "in the performance of a contract for carriage by air, for the purpose of loading, delivery or trans-shipment, any damage is presumed, subject to proof to the contrary, to have been the result of an event which took place during air transport". Second, if a contract of carriage stipulates that goods would be carried by air, and a carrier arbitrarily changes to another transport mode (e.g. by sea) without the consent of the consignor. Thus, under these two circumstances, the Montreal Convention on air transport can regulate marine navigation; navigators need to be aware that their liability is regulated by the air carriage convention rather than a marine convention.

Regardless of the fact that the RR are not applicable in the two cases mentioned above, Article 82 (a) does not suffice to harmonise other conflicts with air transport conventions, if the mode of navigation causing damages cannot be proved. For instance, suppose there is a multimodal-transport contract, including (international) air and marine navigation; some goods are carried by the modes agreed by the carrier and the consignee (not the second circumstance mentioned above), and the goods are damaged; however, the mode of transport resulting in damages is not identified (if the mode is known, it is the first circumstance mentioned above) (Diamond, 2009; De Wit, 2010). Since the navigation mode causing damages is unknown, it is debatable whether a maritime convention (e.g. the RR) applies or not.

Similarly, Article 82's subparagraphs (b), (c) and (d) prevent the RR to a limited extent from conflicting with any existing convention which applies for the types of navigation governing carriage by road, rail and inland waterways. Potential conflicts would arise between the RR and a broad range of sea-and-road transport instruments (Thermo Engineers v Ferrymasters Ltd); the CMR is one of these and applies compulsorily. Under Subparagraph (b), the RR merely scratch the surface of the problem of conflicting rules between the sea and the road navigation (e.g. the CMR Article 2) for a roll-on and roll-off (ro-ro) carriage, in which the goods carried "remain loaded on a road cargo vehicle carried on board a ship". Therefore, Article 82 (b) will prevent 
the RR from prevailing over the CMR, if only "goods ... remain loaded on a road cargo vehicle carried on board a ship". That is, in the event of a ro-ro contract of carriage, the RR would not conflict with the CMR which apply to the whole carriage. Nevertheless, other potential conflicts still remain under this subparagraph as to carriage by road and sea.

Likewise, the same problem also applies to the RR Article 82 subparagraphs (c) and (d). Under Subparagraph (c), the RR come into play as the "supplement to the carriage by rail", without a clear definition of "supplement" (Sturley et al, 2010). Under Subparagraph (d) on inland waterways carriage, the RR are prevailed over in the very limited case of carriage "without trans-shipment both by inland waterways and sea"; however, in this case, the Budapest Convention (CMNI Article 2.2) may not be applicable. Consequently, there is a possibility that an inland waterway carriage without trans-shipment both by inland waterways and sea is governed by neither the RR nor the Budapest Convention.

Therefore, Article 82 has not addressed very well conflicts between conventions on different modes of transport in cases of multimodal carriage. These problematic provisions cause legal uncertainties for navigators. To address the conflicts which arise from litigation over allocated (because unprovable) damage or loss, there are two options: first, to admit that both the RR and a potential conflicting carriage convention are applicable, so that either puts Article 82 within another chapter (rather than the current Chapter 17 "matters not governed by this Convention [RR]"), or maintain that Article 82 be part of Chapter 17 of the RR, amending the title of Chapter 17 (e.g. to "Matters suspending the Convention's application"); second, to clearly state which convention prevails over the others, or to set out a uniform level of liability in the event of unallocated damage, loss or delay (Si and Guo, 2008).

\section{LIMITED NETWORK APPROACH FOR CONFLICTING LIABILITY OF}

NAVIGATORS. RR Article 26 aims to establish a limited network system on carriers' liability with regard to maritime-plus multimodal transport, in order to reduce the conflicts between the RR and other international instruments. For the application of this Article, it must be proved which navigation mode is liable for damages through the proof of the place where damages occurred (Rasmussen, 2010). However, if it cannot be proved where the event (loss, damage, or delay caused) occurred, or if the damage was caused during one leg and continued during following legs, Article 26 is not applicable (De Wit, 2010). Thus, if a case falls outside this Article's ambit, Article 26 itself cannot avoid the conflicts between compulsory rules of different modes of transport (Diamond, 2009).

Moreover, Article 26 has not dealt with the relationships between the RR and mandatory national laws which conflict with the RR. This is because the words "international instruments" (Article 26) do not cover national laws, so Article 26 does not apply.

Furthermore, the use of the words "international instrument" in Article 26 implies regulation of regional economic organisations, and thus they have a broader connotation than the word "convention" (between nations) in Article 82 (Rasmussen, 2010). It is worth noting that Article 26 does not circumscribe the international instruments like those "in force at the time this Convention [i.e. the RR] comes into force" (Article 82); rather it embraces instruments activated "at the time of such loss, damage 
or event or circumstance causing delay" (van der Ziel, 2009). As we have seen, the RR might be overridden by certain future international instruments. Thus it must be borne in mind that an uncertain number of potential instruments could lead to lack of predictability on a worldwide level, and increasing legal risks.

Therefore, in the three categories of circumstances mentioned above, it is difficult to predict how potential conflicts among different transport modes can be resolved. These conflicts could also promote legal uncertainty concerning similar cargo litigation in different jurisdictions, and accompanying increased legal costs. In order to handle the conflicts between the RR and related national laws, the wording "international instrument, at the time of such loss, damage or ... delay" needs to be replaced and ensure that merely "international conventions" "in force at the time this Convention [i.e. the RR] comes into force" prevailing over the RR. This new extension within Article 26 will regulate the relationships between the RR and national instruments. (Namely, the RR could prevail over the national instruments).

5. CONCLUSION. In short, the Rotterdam Rules include scope for maritime-plus coverage, applying to all modes of transport. However, they have not sufficiently dealt with the conflicts between various rules for different kinds of transportation and navigation. As regards multimodal transport containing a seaborne leg, the RR could potentially conflict with a considerable number of international conventions, instruments and national laws, which govern air, land and marine navigation. Indeed, the conflicts become more difficult to harmonise when these rules apply compulsorily on air or land, or inland waterway legs.

To avoid such conflicts, Articles 82 and 26 of the RR should cater for certain conflicts among various legs in order to achieve a uniform sea cargo regime, but, as mentioned above, they only apply to a limited number of circumstances from a wide possible range of conflicting events. Owing to this, unaddressed conflicts will contribute to a considerable degree of uncertainty.

This issue of legal uncertainty is of importance from at least two perspectives. On the one hand, a party would have difficulty in ascertaining its legal rights and liability when it enters a contract of carriage. Article 26 itself has not addressed the issue that in some circumstances a contracting state under the RR and another international convention may face incompatible obligations (Sturley at al., 2010). Additionally, when a particular issue arises within a jurisdiction, it is likely to face considerable legal costs to ensure compliance with related instruments and national laws. On the other hand, from the perspective of a group of contracting states with similar problems, despite the omission of any provision allowing the contracting state to embrace its national law in Article 26, it is very difficult for a court to take account of both the Convention itself and of national laws (Bell, 2010). This is because the national law regarding the damages and loss may be governed by foreign law, but a court usually has difficulty in identifying appropriate applicable laws, and also in dealing with the conflicts between different mandatory rules of the international carriage conventions which themselves are already very complex.

A comprehensive safeguard may address the problems of conflicts caused by Articles 82 and 26. An earlier draft of the RR stated that "nothing contained in this Convention (the RR) prevents a Contracting State from applying any other international instrument which is already in force at the date of this Convention and that 
applies mandatorily to contracts of carriage of goods primarily by a mode of transport other than carriage by sea" (RR Draft Article 89).

\section{ACKNOWLEDGMENT}

I am indebted to Professor Rhidian Thomas (Swansea University) and Professor Simon Baughen (Swansea University) for their enlightening comments on this article. An early draft of this article combined with economic justifications for uniform seaborne cargo rules has been presented at the Forums of National University of Ireland and City University of London.

\section{REFERENCES}

Bell, M. K. (2010). Forget What You Intended: Surprisingly Strict Liability and COGSA versus Carmack, Transportation Law Journal, 18, 57-61.

Berlingieri, F. (2009). A Comparative Analysis of the Hague-Visby Rules, the Hamburg Rules and the Rotterdam Rules, UNCITRAL Working Groups Document, 1, 2-25.

Diamond, A. (2009). The Rotterdam Rules. Lloyd's Maritime and Commercial Law Quarterly, 445-465.

De Wit, R. (2010). Minimal Music: Multimodal Transport Including a Maritime Leg Under the Rotterdam Rules, in D Rhidian Thomas (ed) The Carriage of Goods by Sea under The Rotterdam Rules, Lloyd's List, $105-107$.

Franco, M. (2012). Multimodal Transport After the Rotterdam Rules: Will It Work This Time? The Journal of Internatinal Maritime Law, 18, 210-215.

Hancock, C. (2009). Multimodal Transport under the Convention, in D R. Thomas (ed) A New Convention on the Carriage of Goods by Sea - The Rotterdam Rules: An Analysis of the UN Convention on Contracts for the International Carriage of Goods Wholly or Partly by Sea, Lawtext, 34-51.

League of Nations (1929). Convention for the Unification of Certain Rules Relating to International Carriage by Air (the Warsaw Convention), 12 October 1929, 49 Stat. 3000, 137 LNTS 1.

Rasmussen, U. L. (2010). Additional Provisions Relating to Particular Stages of Carriage, in The Rotterdam Rules 2008, Wloters Kluwer, 143-146.

Sturley, M. F., Fujita, T. and van der Ziel, G. (2010). Carrier's Liability, in The Rotterdam Rules: The UN Convention on Contracts for the International Carriage of Goods Wholly or Partly by Sea Sweet \& Maxwell, 62-75.

Si, Y.Z. and Guo, P. (2009). 'Limits of Liability', in The Rotterdam Rules 2008 (Wolters Kluwer), 259-262.

Thermo Engineers v Ferrymasters Ltd. (1981). 1 W.L.R. 1491.

Ulfbeck, V., (2010). Multimodal Transports in the United States and Europe - Global or Regional Liability Rules? Tulane Maritime Law Journal, 34, 37-88.

UN. (1952). Convention Concerning the Carriage of Goods by Rail (CIM), 25 October 1952, 241 U.N.T.S. 336

UN. (1956). Convention on the Contract for the International Carriage of Goods by Road (CMR), 19 May 1956, 399 U.N.T.S. 189, amended by the 1978 Protocol.

UN. (1970). International Convention Concerning the Carriage of Goods by Rail (COTIF), 7 February 1970, 1101 U.N.T.S.226.

UN. (1978). The United Nations Convention on the Carriage of Goods by Sea (Hamburg Rules), 31 March 1978, U. N. Doc.A/CONF.89.

UN. (1979). Protocol to Amend the International Convention for the Unification for Certain Rules of Law Relating to Bills of Lading (Hague-Visby Rules), 23 February 1968, 1977 Gr.Brit.T.S.No.83.

UN. (1980). United Nations Convention on International Multimodal Transport of Goods (Multimodal Convention), Doc. TD/MT/CONF/16.

UN. (1999). Convention for the Unification of Certain Rules for International Carriage by Air (the Montreal Convention), 28 May 1999.

UN. (2001). Budapest Convention on the Contract for the Carriage of Goods by Inland Waterway (CMNI).

UN. (2008). The United Nations Convention on Contracts for the International Carriage of Goods Wholly or Partly by Sea (Rotterdam Rules), 11 December 2008, UN Doc. C.N.790.

US. (1906). Carmack Amendment, 49 U.S. Code $\$ \$ 11706,14706$.

van der Ziel, G., (2009). Multimodal Aspects of the Rotterdam Rules. Revue de Droit Uniforme, 945-958. 